\title{
Whole grains and CVD risk
}

\author{
Chris J. Seal \\ School of Agriculture, Food \& Rural Development, Agriculture Building, University of Newcastle upon Tyne, \\ Newcastle upon Tyne NE1 7RU, UK
}

\begin{abstract}
There is an increasing body of evidence, including that from prospective population studies and epidemiological observational studies, suggesting a strong inverse relationship between increased consumption of wholegrain foods and reduced risk of CVD. This evidence has translated into specific dietary recommendations in the USA to consume at least three servings of whole grain per $\mathrm{d}$, and has informed the development of specific health claims for wholegrain foods both in the USA and in Europe. Wholegrain foods are rich sources of many nutrients and phytochemicals, including complex carbohydrates, dietary fibre, minerals, vitamins, antioxidants and phyto-oestrogens such as lignans. Many of these components are lost from the grain during processing and although some may be replaced (such as in the mandatory fortification of white flour), this practice ignores the possible synergistic effects of the 'natural' constituents. The notion that wholegrain foods are simply a source of dietary fibre has been dispelled, although the additional components that contribute to the health benefits have not been clearly identified. In addition, the mechanisms by which wholegrain foods may have their effect are poorly understood. At present there are few strictly-controlled intervention studies that have confirmed a beneficial effect of increased consumption of wholegrain foods, demonstrated the level of consumption required to elicit a beneficial effect or provided evidence of modes of action. Although wholegrain foods are considered amongst the healthiest food choices available, their consumption falls well below current recommendations, which have been based mainly on epidemiological evidence. Well-controlled intervention studies are needed to provide more detailed mechanistic evidence to support the health claims and findings which can be used to develop effective public health strategies to promote whole-grain consumption.
\end{abstract}

\section{Whole grain: CVD: Antioxidants: Disease risk}

\section{Whole grains}

Whole grains as foods in the human diet are not a new invention. Evidence of their consumption can be found in ancient petroglyphs and remains have been found in preserved coprolites. Stable-isotope signatures in hair from 5200-year-old Ice Man are consistent with the consumption of vegetarian diets based on $\mathrm{C}_{3}$ plants (Macko et al. 1999). Until relatively recent history grains were crushed and 'milled' to produce coarse flours and were essentially consumed as 'whole grains', with a poor and incomplete separation of the bran and germ from the endosperm. With the development of the roller mill separation became more efficient, and since that time consumption of refined grains has increased dramatically, especially in Western industrialised countries, almost to the exclusion of whole grains. Consumption of whole grains has increased slightly since the 1970s when the 'fibre hypothesis' promoted the potential health benefits of fibre-rich foods, including those derived from whole cereal grains (Trowell, 1979).

The cereal grains consumed by man are the seeds of the Gramineae family of grasses. The most commonly consumed are wheat, rice and maize, although barley, oats, rye, millet and sorghum are more common in some countries than in others depending on climate and cultural differences (Southgate, 2000). Whole grains are composed of three principal parts, the bran, the germ and the endosperm; the relative amounts of these constituents differ from one species to another. For example, brown rice has a very low bran content $(30 \mathrm{mg} / \mathrm{g})$ compared with maize (approximately $60 \mathrm{mg} / \mathrm{g}$ ) and wheat $(\leq 160 \mathrm{mg} / \mathrm{g}$ ). Similarly, the soluble fibre content of oats, barley and rye is much higher than that found in wheat. Bran and germ contain many nutrients, and non-nutrient inorganic and organic components, many of which are lost during the refining process; the extent of the loss depends on the

\footnotetext{
Abbreviations: CRP, C-reactive protein; GI, glycaemic index.

Corresponding author: Dr Chris Seal, fax +44 191 2226720, email chris.seal@ncl.ac.uk
} 
extent of extraction (Smith et al. 2003). Although some of these constituents can be replaced into the refined flour through mandatory fortification policies, there is a consensus view (Pereira et al. 2001; Slavin, 2003) that suggests that consumption of the fortified product is not the same as consumption of the original grain product with its more complex structure. In the majority of modern milling practices the individual components of the grain are separated but then re-constituted to re-form the wholegrain (wholemeal) flour. The American Association of Cereal Chemists have sought to produce a definition of whole grain that will be of benefit to consumers and food manufacturers. The definition, which was approved and adopted in 1999, is: 'Whole grains shall consist of the intact, ground, cracked or flaked caryopsis, whose principal anatomical components - the starchy endosperm, germ and bran - are present in the same relative proportions as they exist in the intact caryopsis' (American Association of Cereal Chemists, 2005).

It is important to note that wholegrain foods are not 'unprocessed'; the average consumer does not eat intact whole grains except in small quantities in some mueslis or when added as texture in some breads. Grains are altered mostly during milling in order to improve flavour, colour, palatability, appearance and cooking characteristics as well as to provide shelf-stable products. It is unusual to consume wholegrain flours in which the constituent parts have not been separated during the milling process, with the exception generally of stoneground or specialist flours. In addition, flours themselves are subjected to considerable shear forces during milling. This, together with the fractionation and re-constitution procedures will, inevitably, result in changes to the gross morphology of the product and most likely the chemical composition.

\section{Definition of wholegrain foods and health claims}

The US Food and Drug Administration was the first authority to allow a health claim based on wholegrain foods, which was approved by Congress in 1999 under the Food and Drug Administration Modernisation Act (Wiemer, 2002). The health claim was approved as an 'authoritative statement' following an industry-led submission by General Mills (Minneapolis, MN, USA) and reads as follows: 'Diets rich in wholegrain foods and other plant foods and low in total fat, saturated fat, and cholesterol may reduce the risk of heart disease and some cancers' (Food and Drug Administration, 1999). A second, modified, health claim was approved in 2003 (Food and Drug Administration, 2003). The difference between the two statements is that because fat per se is not associated with increased risk of heart disease (it is the saturated fat and cholesterol that are the problem) foods bearing the second health claim do not need to meet the nutrient content claim of a 'low-fat' food, but can contain moderate levels of fat. The Food and Drug Administration (1999) have defined a wholegrain food as a product containing $>51 \%$ whole grain by weight per reference amount customarily consumed per $d$. In order to use the health claim, and consider the food as a 'wholegrain food', the whole grain ingredients must be present in sufficient quantity to characterise the food (hence the dominant or first ingredient in the ingredient list must be a whole grain), and the food must provide a minimum of $16 \mathrm{~g}$ whole grain/reference amount customarily consumed (Richardson, 2003). Europe has followed the US lead, first with the Joint Health Claims Initiative concluding that 'people with a healthy heart tend to eat more wholegrain foods as part of a healthy lifestyle'. The process leading to this statement, and the evidence considered, has been recently reviewed by Richardson (2003). The Swedish Nutrition Foundation (2003) issued the stringent, if rather long, statement 'A healthy lifestyle and a well balanced diet rich in wholegrain products reduces the risk for (coronary) heart disease. The product $\mathrm{X}$ is rich in wholegrains (contains $\mathrm{Y} \%$ of wholegrain)'. Thus, although there is considerable evidence that diets rich in wholegrain foods are associated with reduced risk of some cancers and type 2 diabetes, the focus driven through the food industry has been on the association with reduced CVD.

\section{Whole grains and CVD risk, epidemiological and experimental evidence of benefit}

CVD encompass a range of pathologies, including disease of the arteries supplying blood to the muscles of the heart (CHD or IHD), the brain (cerebrovascular disease or stroke) and the extremities, especially the legs (peripheral vascular disease, e.g. deep-vein thrombosis). The disease involves the processes of atherosclerosis (lesions of the arteries caused by fat deposition), arteriosclerosis (caused by $\mathrm{Ca}$ deposition) and thrombosis (blood clotting). Collectively CVD are the most common causes of death in Western countries, accounting for $>40 \%$ of all deaths. CHD is the single largest cause of death in the UK (British Heart Foundation, 2005) and US (American Heart Association, 2005).

Recognising the protective association between the consumption of wholegrain foods and CVD is not new. Trowell (1972) first proposed that wholegrain foods are protective against IHD, but this proposal has been re-interpreted as a 'fibre' hypothesis rather than a 'highfibre food' hypothesis (Anderson et al. 2000; Anderson, 2004), with the consequence that 'fibre' has become the focus of public health recommendations rather than placing the emphasis on whole foods. In one of only a small number of studies from the UK Morris et al. (1977) have reported an $80 \%$ reduction in heart attacks in men when those with the highest cereal-fibre intake compared with those with the lowest intakes. Subsequently, a number of large epidemiological and controlled studies, mainly based in the USA, have reported negative associations between whole-grain intake and risk for CHD. These studies have been reviewed by Anderson et al. (2000), and their analysis has been recently updated by Anderson (2003). The results of these meta-analyses confirm the suggestion that whole grains are more effective in reducing risk of CVD than other foods commonly eaten such as fruit or vegetables, and that this effect is independent of cereal fibre. Indeed, for cereal fibre alone Anderson (2003) has 
Table 1. Effects of whole-grain consumption on CVD risk ${ }^{\star}$

\begin{tabular}{|c|c|c|c|}
\hline Risk factor or end point & Study and no. of subjects & Outcome & Reference \\
\hline Death rates from CVD & $\begin{array}{l}\text { lowa Women's Health Study (baseline } \\
\text { data from 1984, follow-up to 1995) } \\
34333 \text { women }\end{array}$ & $\begin{array}{l}\text { HR of all CVD across quintiles of } \\
\text { whole-grain intake was } 0.82 \\
(95 \% \mathrm{Cl} 0.66,1.01 ; P=0.02) \\
\text { HR for deaths from } \mathrm{CHD} \text { across quintiles } \\
\text { of whole-grain intake was } 0.82 \\
(95 \% \mathrm{Cl} 0.63,1.06 ; P=0.03) \\
\text { HR for deaths from stroke and other } \\
\text { CVD were not significantly different } \\
\text { across quintiles of whole-grain intake }\end{array}$ & Jacobs et al. (1999) \\
\hline $\begin{array}{l}\text { Incidence and deaths } \\
\text { from IHD }\end{array}$ & $\begin{array}{l}\text { California Seventh-day Adventists } \\
\text { (baseline data from 1976, 6-year } \\
\text { follow-up) } 13857 \text { men, } 20341 \text { women }\end{array}$ & $\begin{array}{l}\text { RR of fatal IHD was lower }(0.89 \\
P<0.005) \text { and non-fatal IHD was } \\
\text { lower }(0.56 ; P<0.01) \text { in those who } \\
\text { preferred wholegrain bread compared } \\
\text { with those who preferred white bread }\end{array}$ & Fraser (1999) \\
\hline $\begin{array}{l}\text { Incidence and deaths } \\
\text { from CHD }\end{array}$ & $\begin{array}{l}\text { Nurses' Health study (baseline data from } \\
\text { 1984, average 10-year follow-up) } \\
75521 \text { women }\end{array}$ & $\begin{array}{l}\text { RR for cases of } \mathrm{CHD} \text { across quintiles } \\
\text { of whole-grain intake was } 0.47(95 \% \\
\mathrm{Cl} 0.27,0.79 ; P=0.006) \text { for never } \\
\text { smokers, and was } 0.79(95 \% \mathrm{Cl} 0.62 \text {, } \\
1.01 ; P=0.07) \text { for the full cohort }\end{array}$ & \\
\hline $\begin{array}{l}\text { Incidence of ischaemic } \\
\text { stroke }\end{array}$ & $\begin{array}{l}\text { Nurses' Health study (baseline data from } \\
\text { 1984, average 12-year follow-up) } \\
75521 \text { women }\end{array}$ & $\begin{array}{l}\text { RR of incident IHD across quintiles of } \\
\text { whole-grain intake was } 0.69(95 \% \mathrm{Cl} \\
0.50,0.98 ; P=0.03)\end{array}$ & Liu et al. (2000b) \\
\hline $\begin{array}{l}\text { Death rates from } \mathrm{CHD} \\
\text { and CVD }\end{array}$ & $\begin{array}{l}\text { Bread eaters in Norwegian County Study } \\
\text { (data from } 1977 \text { to 1994) } 16933 \text { men, } \\
16915 \text { women }\end{array}$ & $\begin{array}{l}\text { HR of death from CHD across quintiles } \\
\text { of wholegrain bread consumption was } \\
0.75(95 \% \mathrm{Cl} 0.65,0.88 ; P=0.006) \\
\text { HR of CVD across quintiles of } \\
\text { wholegrain bread consumption was } \\
0.77(95 \% \mathrm{Cl} 0.60,0.98 ; P=0.016)\end{array}$ & Jacobs et al. (2001) \\
\hline $\begin{array}{l}\text { Incidence of coronary } \\
\text { artery and ischaemic } \\
\text { stroke }\end{array}$ & $\begin{array}{l}\text { Atherosclerosis Risk in Communities } \\
\text { cohort (baseline data in 1987-9, } \\
11 \text {-year follow-up) } 11940 \text { subjects }\end{array}$ & $\begin{array}{l}\text { HR of incident coronary artery disease } \\
\text { across quintiles of whole-grain } \\
\text { intake was } 0.72(95 \% \mathrm{Cl} 0.53 \\
0.97 ; P=0.05) \\
\text { HR of incident ischaemic stroke across } \\
\text { quintiles of whole-grain intake was } \\
0.75(95 \% \mathrm{Cl} 0.46,1 \cdot 22 ; P=0.15)\end{array}$ & Steffen et al. (2003) \\
\hline $\begin{array}{l}\text { Non-fatal myocardial } \\
\text { infarction and fatal } \\
\text { CHD }\end{array}$ & $\begin{array}{l}\text { Health Professionals Follow-up study } \\
\text { (data from } 1986 \text { to 2000) } 42850 \text { men }\end{array}$ & $\begin{array}{l}\mathrm{HR} \text { of } \mathrm{CHD} \text { between highest and lowest } \\
\text { quintile of whole-grain intake was } 0.82 \\
(95 \% \mathrm{Cl} 0.70,0.96 ; P=0.01)\end{array}$ & Jensen et al. (2004) \\
\hline
\end{tabular}

$H R$, hazard ratio; $R R$, relative risk.

*Unless otherwise stated HR or RR have been reported using any fully-adjusted model including all adjustments for demographic, dietary and non-dietary factors and the subject numbers shown are the numbers in the adjusted model.

demonstrated that there is no protective effect against CVD, suggesting that the bran and outer germ are important factors in the protective mechanisms associated with whole grains. A brief summary of the important larger studies is shown in Table 1 . In reporting the effects of wholegrain foods on disease risk it is important to note that whole-grain intake can be a marker of a generally healthier lifestyle, including increased physical activity and lower smoking rates, which are themselves key factors in determining heart disease risk (see Anderson et al. 2000). Thus, the data shown in Table 1 show the results of full-models adjustments. In all cases the full-models adjustments reduce the significance of the whole-grain effect compared with unadjusted data, but still support the overall observation of reduced risk with increasing wholegrain intake.
In addition to the larger population-based studies there are some smaller studies showing positive effects of increased whole-grain intake on measures of cardiovascular function. For example, Erkkilä et al. (2005) in a study with 229 post-menopausal women with established coronary artery disease have shown that those women consuming more than the median intake of six servings of whole grains per week have a lower decline in minimum coronary artery diameter and show a trend towards lower progression in percent stenosis over a 3-year follow-up. In a smaller study with twenty-one non-hypertensive men Hallfrisch et al. (2003) have reported that consuming high-fibre diets based on insoluble fibre (brown rice and wheat) and/or soluble fibre (barley) results in lowering of systolic, diastolic and mean arterial pressure compared with the Step 1 American Heart Association diet. 


\section{Mechanisms of action}

Very few studies have been undertaken on the physiological effects of consuming diets high in wholegrain foods, and thus the mechanisms of action of these products remain somewhat speculative. There are, of course, additional complications associated with unravelling the effects of whole foods compared with single nutrients or pharmacological agents. As discussed previously, whole grains are derived from a range of different species, they are consumed in a variety of different forms and thus they contribute different patterns of nutrients and bio-active compounds to the diet. Thus, it is highly likely that no single component or 'mechanism' will account for their beneficial effects. Rather, it is probably the combination of a range of different synergistic processes that are modulated or improved and result in an overall health benefit.

\section{Antioxidant effects of wholegrain foods}

Antioxidants include a wide range of compounds that delay or prevent pro-oxidant-initiated oxidation of substrates and are present in a variety of forms in foodstuffs (Halliwell et al. 1995). Thus, antioxidants include many molecules such as minerals, vitamins, proteins, carbohydrates and polyphenolics that are capable of donating an electron(s) to a pro-oxidant. Antioxidants in foods may exert their effects in the gut lumen or, once absorbed, in cells and tissues within the body. These 'exogenous' sources of antioxidants contribute to the body's overall antioxidant potential, which also includes 'endogenous' antioxidant molecules and enzymes synthesised within cells in response to oxidative stress. The balance between endogenous and exogenous antioxidants in moderating oxidative stress is a matter of some conjecture, since methods for measuring antioxidant status are very broad in their specificity and cannot distinguish between the different molecular species (Cao \& Prior, 1998). In general, however, avoidance of oxidative stress is important in protecting the body against the consequences of oxidative damage to DNA, proteins and lipids (Sies et al. 2005). Unsaturated fatty acids incorporated into LDL are very prone to oxidative damage and oxidised LDL are strongly atherogenic. Improvements in antioxidant status and concomitant reduction in LDL oxidation products are therefore important in reducing cardiovascular risk.

Whole grains contain many water-soluble and fatsoluble antioxidants, including trace minerals, vitamins, phenolic acids, lignans, phytic acid, tocopherols, tocotrienols and phyto-oestrogens. These antioxidant compounds have been extracted and measured by several methods (Kähkonen et al. 1999; Zielinski \& Kozlowska, 2000; Adom \& Liu, 2002; Halvorsen et al. 2002). The majority of the procedures described in these studies rely on the use of solvents to produce an antioxidant extract that clearly demonstrates a range of antioxidant contents for the different products. However, these extraction procedures are essentially 'non-physiological' and do not necessarily reflect the available antioxidant that can be released from the food matrix during passage through the gastrointestinal tract. An in vitro procedure has recently

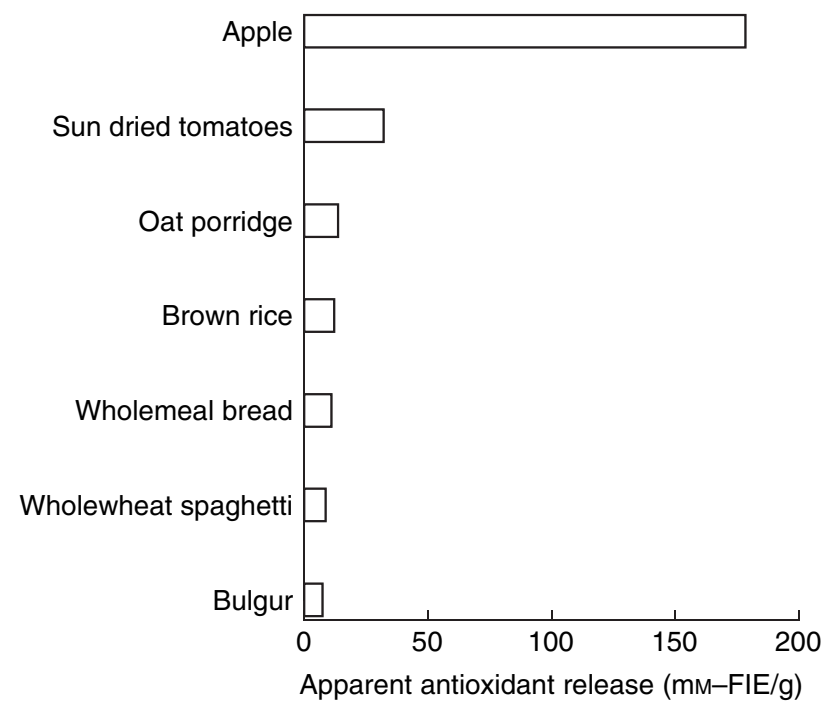

Fig. 1. Apparent antioxidant content (expressed as $\mathrm{Fe}^{2+}$ equivalents (FIE); $\mu \mathrm{M}$ ) in some wholegrain foods in comparison with fruit determined using the ferric-reducing activity power assay. (Data from Nagah \& Seal, 2005.)

been used to mimic the different phases of digestion through the intestines, using sequential acid, alkali and enzymic steps to provide a more physiological measure of available antioxidant (Nagah \& Seal, 2005). The results demonstrate that antioxidant release is dependent on the incubation conditions and suggest that as digestion progresses antioxidants can be released from within the food matrix. The apparent antioxidant content of the wholegrain foods is higher than that of refined-grain alternatives, but much lower than that measured in fruits and vegetables (Fig. 1). Wholegrain foods therefore have potential as sources of antioxidants, but the extent to which their consumption can affect antioxidant status in animals or man is not clear.

The impact of consuming wholegrain products on antioxidant status has been measured using both animals and human subjects. For laboratory rats fed diets containing $500 \mathrm{~g}$ wholemeal wheat, wholemeal rye or brown-rice flours $/ \mathrm{kg}$ for $21 \mathrm{~d}$ the plasma antioxidant capacity is not different from that of rats fed a control diet containing $500 \mathrm{~g}$ maize starch/kg (Nagah, 2005). The antioxidant content of urine is highest for rats fed wholemeal rye, although the antioxidant content of faeces is similar for rats fed all three wholegrain diets (Fig. 2), albeit higher than that for the animals fed maize starch. The CHEW-IT study (Jones et al. 2004a,b) was a whole-grain intervention study with human subjects in which participants were asked to consume three $23 \mathrm{~g}$ servings of wholegrain food per $\mathrm{d}$ for 8 weeks and then increase their wholegrain food consumption to six $23 \mathrm{~g}$ servings per $\mathrm{d}$ for a further 8 weeks. Fasting blood samples and $24 \mathrm{~h}$ urine collections were taken at baseline, 8 and 16 weeks. The antioxidant capacity of plasma shows no difference during the intervention (Fig. 3(a, b)). However, the antioxidant output in urine increases progressively with increasing wholegrain intakes (Fig. 3(c, d)). The lack of response in plasma antioxidant measures is disappointing as compliance 
(a)

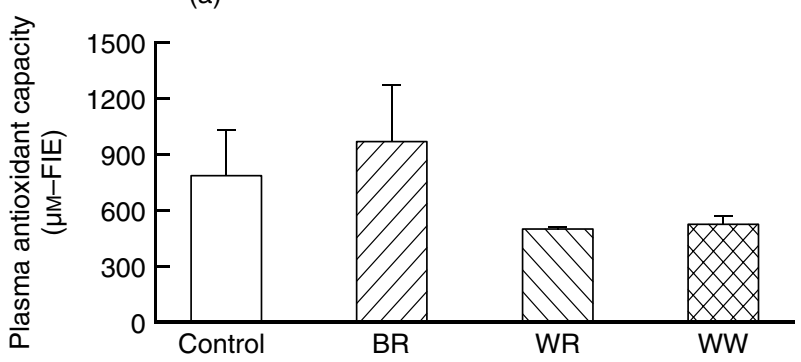

(b)

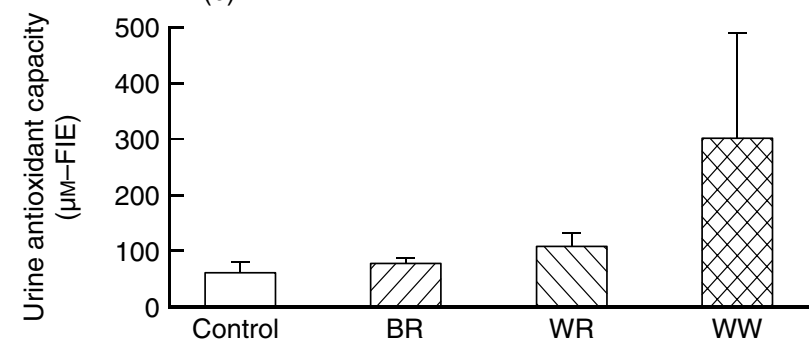

(c)

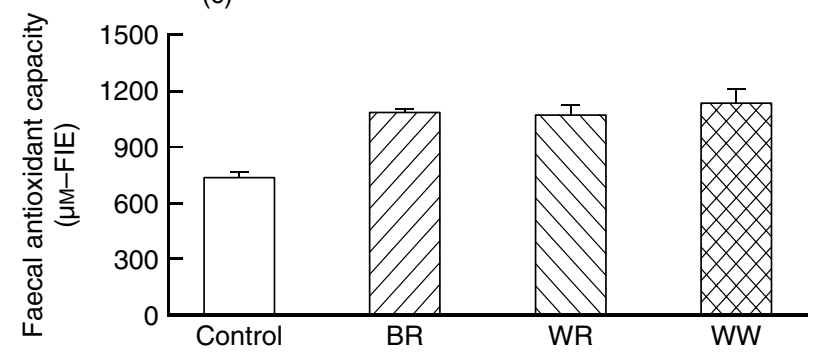

Fig. 2. Antioxidant capacity (expressed as $\mathrm{Fe}^{2+}$ equivalents (FIE); $\mu \mathrm{M}$ ) of plasma (a), urine (b) and faeces (c) in rats fed semi-purified diets containing $500 \mathrm{~g}$ maize starch (control; $\square$ ), brown-rice flour (BR; III), wholemeal rye flour (WR; III) or wholemeal wheat flour $\left(\mathrm{WW} ; x^{\prime}\right) / \mathrm{kg}$, determined using the ferric-reducing activity power assay. Urine and faecal samples were collected during a $7 d$ balance period at the end of the $21 \mathrm{~d}$ feeding period. Plasma samples were separated from whole blood taken at the end of the $21 \mathrm{~d}$ feeding period. Values are means with their standard errors represented by vertical bars for five rats per group. (From Nagah, 2005.)

with the intervention was good (AR Jones, S Kuznesof, DP Richardson and CJ Seal, unpublished results), perhaps suggesting that fasting blood samples are not good indicators of antioxidant status in these healthy individuals. In the rat model plasma samples also show no difference despite large intakes of very different wholegrain products. Interestingly, however, urinary antioxidant output in both studies appears to respond to changes in the diet. Increased urinary output may be indicative of watersoluble components that have been absorbed through the gut and then excreted in urine. Transient changes in the antioxidant capacity of plasma have been reported following tea consumption (Langley-Evans, 2000; Leenen et al. 2000), with maximum values reached approximately $1 \mathrm{~h}$ after drinking the tea. In the latter study it was found that antioxidant status measured using the ferric reducing ability of plasma assay continues to rise with hourly tea consumption, but the time taken to return to baseline (a)

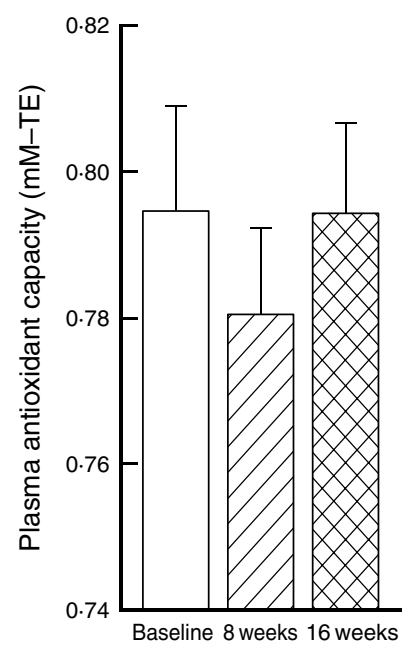

(c)
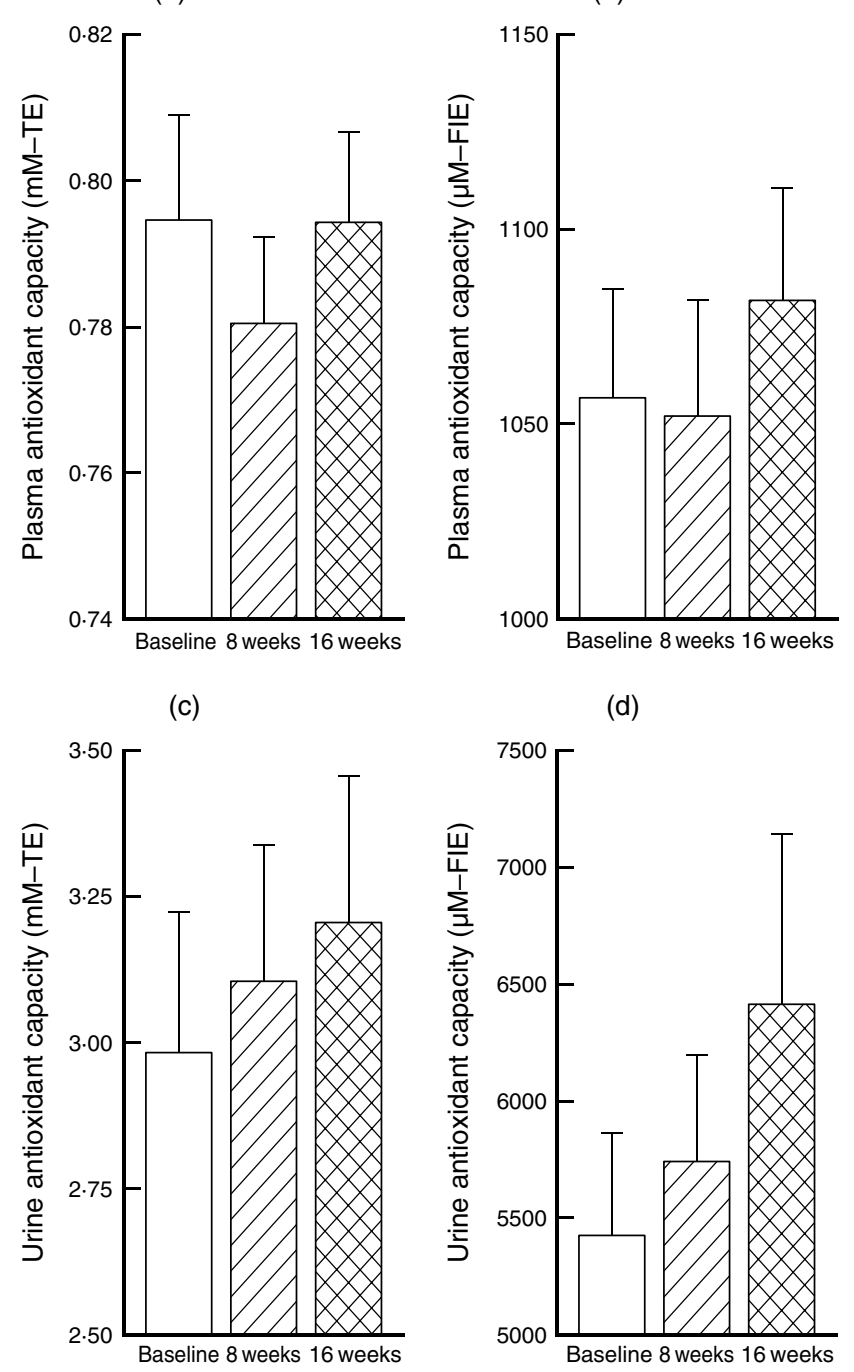

(d)

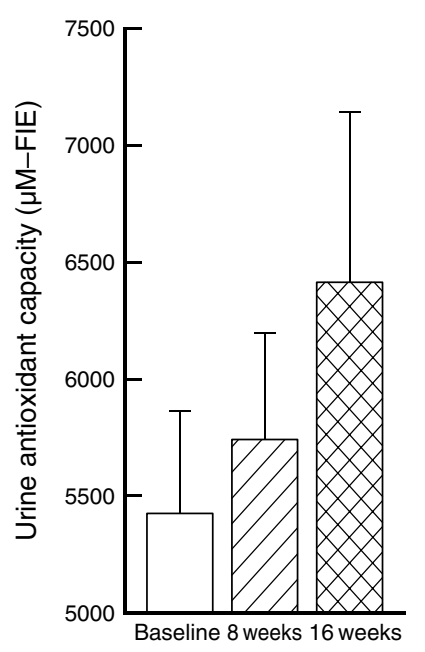

Fig. 3. Antioxidant capacity of plasma (a, b) and $24 \mathrm{~h}$ urine (c, d) samples from human subjects consuming three $23 \mathrm{~g}$ servings of wholegrain food per $d$ for 8 weeks followed by six $23 \mathrm{~g}$ servings of wholegrain food per $\mathrm{d}$ for an additional 8 weeks, determined using the ferric-reducing activity power assay (expressed as $\mathrm{Fe}^{2+}$ equivalents (FIE); b, d) and Trolox equivalent antioxidant capacity method (expressed as Trolox equivalents (TE); a, c). ( $\square$ ), Baseline; $(/ I I /), 8$ weeks; $(X), 16$ weeks. Values are means for thirty-two subjects. (Data from A Jones and CJ Seal, unpublished results.)

values was not reported. Consuming meals with wholegrain foods containing higher levels of antioxidants may also result in postprandial fluctuations in apparent antioxidant status and this response would be an area of interest for future research. In addition, the relative insensitivity and lack of specificity of the analytical methods commonly used (the ferric-reducing activity power assay (Benzie \& Strain, 1996) and the Trolox equivalent antioxidant capacity method ( $\operatorname{Re}$ et al. 1999)) may also mask beneficial effects, and further analysis of specific antioxidant compounds present in wholegrain foods and their absence or presence in plasma will be required in order to determine whether they can make a major contribution to antioxidant status. 


\section{Mammalian lignans and whole grains}

The major sources of dietary lignans in human nutrition are the cereals, although fruits and berries also contribute to intake. However, soyabean and flaxseed contain much higher concentrations of lignans than cereals, so intakes can vary greatly between populations for whom these foods are more common in the diet. Within cereals there is also considerable variation in lignan precursors, and rye is particularly high in lignans; thus, populations such as the Finns who consume large quantities of rye products are also likely to have higher intakes.

Lignans are consumed as precursor molecules, predominantly matairesinol and secoisolariciresinol, that are converted to the active mammalian lignans enterolactone and enterodiol by the colonic microflora. With the development of analytical methods for the determination of dietary lignans, the number of precursors identified has increased (Nurmi \& Adlercreutz, 1999). However, the contribution of these precursors to enterolactone and enterodiol concentrations in plasma remains uncertain.

Lignans are potent antioxidant molecules and have been shown to be protective against hormone-related cancers (Pietinen et al. 2001; Pietinen \& Kilkkinen, 2002; Hallmans et al. 2003; Qu et al. 2005). In vitro the lignans do not bind to the oestrogen receptor (Saarinen et al. 2000), but enterolactone inhibits human oestrogen synthetase by binding to the active site of the $\mathrm{P}_{450}$ enzyme (Adlercreutz et al. 1993).

Population data on lignan intakes are largely unreliable since the lignan content of many foodstuffs is not known, especially for the newly-identified precursor molecules. Recently, however, analyses based on new foodcomposition data have become available (for example, see Milder et al. 2005) and they show that early estimates considerably underestimated lignan intake. Also, plasma enterolactone and enterodiol concentrations are strongly correlated with intake (Kilkkinen et al. 2001, 2003; Horner et al. 2002; Johnsen et al. 2004). Furthermore, feeding of wholegrain rye, wheat and brown rice to rats results in higher plasma concentrations and urinary excretion of enterolactone and enterodiol than feeding maize starch (Nagah et al. 2004; Nagah, 2005), as does feeding wholegrain rye to pigs (Bach Knudsen et al. 2003). In both animals and human subjects, however, there is considerable intra-individual variability in plasma concentrations, which may be related to the extent of conversion of plant lignan precursors to mammalian lignans, which is strongly dependent on the activity of the gut microflora (Kilkkinen et al. 2001; Grace et al. 2003; Niemeyer et al. 2003), and the ability to absorb the metabolites (Bowey et al. 2003). The metabolic consequences of elevated plasma enterolactone and enterodiol concentrations have not been elucidated, and more evidence from human studies is required to confirm whether these molecules are involved in reducing CVD risk and to elucidate their mechanisms of action. It is possible that the lignans may possess similar cardioprotective effects to those reported for other polyphenolic compounds, including reducing LDL-cholesterol oxidation, changes in cholesterol synthesis and re-cycling, and changes in the metabolism of triacylglycerols (Zern \&
Fernandez, 2005), although as yet there is limited evidence to support these hypotheses. Men from the Kuopio Ischaemic Heart Disease Risk Factor Study in the highest quartile of serum enterolactone concentrations were found to have a $65 \%$ lower risk of acute coronary events than men from the lowest quartile (Vanharanta et al. 1999). However, serum total cholesterol and LDL-cholesterol concentrations were not found to be different between the quartiles. In a study of post-menopausal women Kreijkamp-Kaspers et al. (2005) have shown a trend for lower total cholesterol and LDL-cholesterol concentrations across tertiles of lignan intake that again was not significant. In a recent analysis of a subgroup of subjects from the Health Professionals Follow-up Study van der Schouw et al. (2005) have reported that concentrations of LDL-cholesterol and apoB tend to increase across quartiles of increasing lignan intake (for LDL-cholesterol: from quartile 4 to quartile $1,9 \% ; P=0.01$ for trend; for apoB: from quartile 4 to quartile $1,9 \% ; P=0.02$ for trend). However, fasting insulin and C-peptide tend to decrease across quartiles of lignan intake (for insulin: from quartile 4 to quartile $1,-11 \% ; P=0.02$ for trend; for C-peptide: from quartile 4 to quartile $1,-25 \% ; P=0.01$ for trend). Both these studies have limitations in the quantification of lignan intake, which was calculated from dietary data collected from a food-frequency questionnaire not specifically designed for this purpose, and no measures of lignan 'status' were determined.

\section{Changes in insulin resistance}

Insulin resistance and hyperinsulinaemia are associated with increased risk of CVD (Shinozaki et al. 1996; Katz et al. 1999; Golden et al. 2002; Uwaifo \& Ratner, 2003). However, the impact of the source and type of carbohydrate on the development of insulin resistance is inconclusive (Daly et al. 1997). In a study using laboratory rats Byrnes et al. (1995) have shown that feeding rapidlydigested starch with a high amylopectin content results in increased plasma insulin concentrations following an intravenous glucose challenge. The mechanisms involved in this increase in insulin resistance have not been elucidated, and it is uncertain whether these results can be extrapolated to man. In acute studies starches that are rapidly digested (high glycaemic index; GI) result in higher postprandial glucose and insulin responses compared with starches that are more slowly digested (lower GI; Seal et al. 2003; Ells et al. 2005). Recurrent postprandial exposure to high plasma glucose and high plasma insulin as a result of habitual consumption of refined high-GI carbohydrate foods may contribute to the development of insulin resistance. Indeed, changing from high-GI foods to low-GI foods has been shown to result in improved insulin sensitivity (for example, see Frost et al. 1998). Wholegrain foods with intact germ and bran may have lower GI values than foods containing refined carbohydrate (Foster-Powell \& Brand-Miller, 1995). However, grinding or milling cereals during processing removes the bran layer and reduces particle size, allowing more rapid digestion by digestive enzymes, and thus wholegrain foods do not necessarily have a lower GI. It would be expected, 
however, that diets rich in wholegrain foods may result in improved insulin sensitivity, and there is some evidence to support this hypothesis from epidemiological studies that have demonstrated associations between lower fasting insulin concentrations and glycaemic response and increased consumption of whole grains (Pereira et al. 1998; Fung et al. 2002). In one study in which insulin sensitivity was measured by intravenous glucose-tolerance test Liese et al. (2003) have shown an increase in insulin sensitivity with increased whole-grain consumption. This association is attenuated, but not removed, when adjustments for lifestyle and anthropometric measurements (BMI and waist circumference) are made. However, inclusion of fibre and $\mathrm{Mg}$ in the model removes the association, suggesting that these factors may account for some of the effect of whole grains on insulin sensitivity. To date there have been no large-scale intervention studies to confirm the beneficial effect of increasing wholegrain food consumption on insulin sensitivity. In one small intervention study in which eleven overweight and obese hyperinsulinaemic men followed a strict dietary regimen in which they ate six to ten portions of whole grains for 6 weeks lower fasting insulin concentrations and improved insulin sensitivity have been reported (Pereira et al. 2002). This study, in a high-risk group whose intakes of wholegrain food exceeded those recommended for the general population, provides evidence of a beneficial effect but requires confirmation in the wider population at intakes that may be achievable in the general population.

\section{Whole grains, inflammation and endothelial function}

Inflammation is now recognised as a major contributor to atherosclerosis and vascular endothelial dysfunction (Ross, 1999), although the mechanisms involved are not clear. Pro-inflammatory mediators, including cytokines such as IL-6, IL-18 and TNF $\alpha$, are known to be elevated in overweight and obese individuals (Esposito et al. 2003). These compounds may affect vascular and endothelial cells resulting in induction of adhesion molecules, oxidative stress and reduction in NO production and cell proliferation, all of which promote atherosclerosis (Haffner, 2003; Plutzky, 2003). Endothelial dysfunction causes enhanced and maintained endothelial deactivation, resulting in elevated plasma concentrations of soluble endothelial adhesion molecules. Serum concentrations of these molecules are strongly related to CVD risk in patients without clinical symptoms of the disease (Brown \& $\mathrm{Hu}$, 2001). C-reactive protein (CRP) is an acute-phase protein secreted by the liver and is also a sensitive marker for subclinical inflammation and CVD risk (Yudkin et al. 1999; Ridker, 2001). The link between CRP, cytokines and insulin resistance remains unclear. Liu et al. (2002) have demonstrated a positive association between plasma high-sensitivity CRP and dietary glycaemic load in 244 healthy middle-aged women from the Women's Health Study, independent of conventional risk factors for IHD. Their results suggest that perturbations in the proinflammatory process may be a mechanism whereby a high intake of rapidly-digested and absorbed carbohydrates (high GI) increases the risk of CVD. In addition, the authors have noted that the dose-response gradient between dietary glycaemic load and high-sensitivity CRP is more apparent for overweight women, thus those who are more prone to be insulin resistant may be at an even higher risk of developing this pro-inflammatory state. A further link with pro-inflammatory changes is shown in the progression from normal glucose tolerance to impaired glucose tolerance with accompanying insulin resistance in which circulating concentrations of plasminogen activator inhibitor-1 and fibrinogen are progressively increased (Festa et al. 1999). To date there are no studies in which markers of inflammatory status or endothelial function have been compared for different whole-grain intakes. However, circumstantial evidence of an association can be drawn from a cross-sectional study of 732 women from the Nurses' Health Study cohort by Lopez-Garcia et al. (2004). In this analysis subjects were divided according to dietary patterns; the 'prudent' pattern included whole grains whereas the 'Western' pattern included refined grains. It was found that the age-adjusted geometric-mean plasma concentrations of CRP and E-selectin show decreasing trends with increasing quintiles of the 'prudent' dietary pattern. In contrast, there are increasing trends with increasing quintiles of 'Western' dietary pattern. Further analysis of the diets from this cohort using a range of diet quality scores (Fung et al. 2005) also demonstrates reduced concentrations of biomarkers of inflammation and endothelial function with higher diet-quality scores for some of the scoring systems. In a larger study of subjects from the National Health and Nutrition Examination Survey 1999-2000 Ajani et al. (2004) have shown that dietary fibre intake is inversely correlated with serum CRP concentration. Unfortunately, the authors do not report the sources of dietary fibre, so it is not possible to determine the contribution of whole grain to fibre intakes. However, since whole grains make a sizeable contribution to fibre intake it is likely that those with the higher fibre intakes will also have higher intakes of whole grains. As a result of their cross-sectional nature these studies do not establish causality, but they clearly suggest that improving diet quality with the inclusion of high-fibre wholegrain food options is a possible mechanism for reducing these important markers of CVD risk.

\section{Whole grains and body weight}

Several studies have investigated the relationship between whole-grain consumption and anthropometric measurements including body weight and BMI, or have included these variables as part of the analysis of large population-based studies. A summary of the larger of these studies is shown in Table 2. The majority of the studies have relied on self-reported body weights and should therefore be viewed with some caution, but overall there is some evidence of a beneficial negative relationship between whole-grain intake and body weight, albeit modest. For the Nurses' Health Study, in which multiple analyses have been carried out (Liu et al. 1999, 2000a,b), the data are a little unclear. In one paper (Liu et al. 2000b) 
Table 2. Effects of whole-grain consumption on body weight and BMI

\begin{tabular}{|c|c|c|}
\hline Study and number of subjects & Outcome & Reference \\
\hline $\begin{array}{l}\text { Nurses' Health Study (data from } \\
\text { baseline in 1984) } 75251 \text { women }\end{array}$ & $\begin{array}{l}\text { No change in BMI across quintiles of whole-grain intake } \\
\left(25 \mathrm{~kg} / \mathrm{m}^{2} \text { for each quintile) }\right. \\
\text { Women with high intakes of whole grain weighed less } \\
\left(25 \cdot 0 \mathrm{~kg} / \mathrm{m}^{2} \text { for lowest quintile of whole-grain intake to }\right. \\
24 \cdot 4 \mathrm{~kg} / \mathrm{m}^{2} \text { for the highest quintile, no measure of statistical } \\
\text { analysis included) }\end{array}$ & $\begin{array}{l}\text { Liu et al. (1999), } \\
\text { Liu et al. (2000b) } \\
\text { Liu et al. (2000a) }\end{array}$ \\
\hline $\begin{array}{l}\text { Framingham Offspring Study (data from } \\
5 \text { th cycle of study, 1991-5) } 1338 \text { men, } \\
1603 \text { women }\end{array}$ & $\begin{array}{l}\text { Participants in the highest quintile of whole-grain intake } \\
\text { tended to have a lower BMI than those in the lowest } \\
\text { quintile of whole-grain intake }\left(26.9 \mathrm{~kg} / \mathrm{m}^{2} \text { for lowest quintile }\right. \\
\text { of whole-grain intake to } 26.4 \mathrm{~kg} / \mathrm{m}^{2} \text { for the highest quintile; } \\
P=0.06)\end{array}$ & $\begin{array}{l}\text { McKeown } \\
\text { et al. (2002) }\end{array}$ \\
\hline $\begin{array}{l}\text { Health Professionals Follow-up study } \\
\text { (data from 1986-1994) } 27802 \text { men }\end{array}$ & $\begin{array}{l}\text { No change in BMI across quintiles of intake at baseline } \\
\left(25 \cdot 6 \mathrm{~kg} / \mathrm{m}^{2} \text { for lowest quintile of whole-grain intake to }\right. \\
24 \cdot 6 \mathrm{~kg} / \mathrm{m}^{2} \text { for the highest quintile) } \\
\text { Multivariate-adjusted weight change over } 8 \text {-year follow-up } \\
\text { was significantly lower across quintiles of whole-grain } \\
\text { intake }(+1.87 \mathrm{~kg} \text { for lowest quintile, }+0.75 \mathrm{~kg} \text { for highest } \\
\text { quintile; } P<0.0001 \text { for trend) }\end{array}$ & $\begin{array}{l}\text { Koh-Banerjee } \\
\text { et al. (2004) }\end{array}$ \\
\hline $\begin{array}{l}\text { lowa Women's Health Study (baseline } \\
\text { data from 1986) } 34492 \text { women }\end{array}$ & $\begin{array}{l}\text { Significant reduction in BMI across quintiles of intake } \\
\left(27 \cdot 2 \mathrm{~kg} / \mathrm{m}^{2} \text { for lowest quintile of whole-grain intake to }\right. \\
26.9 \mathrm{~kg} / \mathrm{m}^{2} \text { for the highest quintile; } P<0.0001 \text { for trend) } \\
\text { Significant reduction in mean waist : hip ratio across quintiles } \\
\text { of whole-grain intake }(0.848 \text { for lowest quintile, } 0.832 \text { for } \\
\text { highest quintile; } P<0.0001 \text { for trend) }\end{array}$ & Jacobs et al. (1998) \\
\hline $\begin{array}{l}\text { lowa Women's Health Study (baseline } \\
\text { data from } 1986 \text { for women matched on } \\
\text { eating } 6 \mathrm{~g} \text { total grain fibre intake/8.3 MJ } \\
(2000 \mathrm{kcal}) \text { per d) } 11040 \text { women }\end{array}$ & $\begin{array}{l}\text { No difference in BMI between group with whole-grain fibre } \\
\text { contributing } 71 \% \text { of total fibre intake compared with group } \\
\text { with refined grain fibre contributing } 77 \% \text { of total grain fibre } \\
\text { intake ( } 27 \cdot 0 \mathrm{~kg} / \mathrm{m}^{2} \text { and } 27 \cdot 2 \mathrm{~kg} / \mathrm{m}^{2} \text { respectively for } \\
\text { each group) }\end{array}$ & Jacobs et al. (2000) \\
\hline
\end{tabular}

BMI reportedly 'did not vary appreciably across quintiles of intake' whereas in another paper (Liu et al. 2000a) 'women with high intake of whole grains ... weighed less'. In their 10-year follow-up of the same cohort Liu et al. (2003) have shown that although BMI increases with time regardless of levels of grain intake, the increases in both body weight and BMI are less with increasing quintiles of whole-grain intake. Interestingly, for the Iowa Women's study cross-sectional data appear to suggest no relationship between whole-grain intake and BMI, albeit using different methods to categorise subjects (Table 2). However, in an 8-year follow-up of this cohort selfreported weight gain has also been shown to be lower for those in the highest quintile of whole-grain intake compared with those in the lowest quintile of whole-grain intake at the second time point. Large changes in wholegrain intake between quintiles of intake over the same period were reported $(-14 \cdot 2 \mathrm{~g} / \mathrm{d}$ for the lowest quintile and $+23.8 \mathrm{~g} / \mathrm{d}$ for the highest quintile), and it is not known whether there was tracking of individuals within the distribution profiles for whole-grain intake. Where similar longitudinal comparisons were made for the Nurses' Health cohort (Liu et al. 2003) a highly-significant $(P=0.02)$ interaction between whole-grain intake and BMI at baseline was found. Further confounding of the results may also have been introduced if the subjects not only changed their whole-grain intakes but also changed their lifestyle in line with those known to be associated with individuals who eat more whole grains (Koh-Banerjee et al. 2004). Whilst there is limited direct evidence of the beneficial effect of whole-grain intake on body weight, there are considerable data on the effects of dietary fibre (Pereira, 2002). Whether body-weight regulation is an important mechanism through which whole grains reduce CVD risk is unclear, and longer-term well-controlled randomised trials investigating this relationship are required.

\section{Summary}

Wholegrain foods are considered amongst the healthiest food choices that are available; however, their consumption remains well below the US recommended level of three servings per d (US Department of Agriculture, 2005). These recommended levels have been proposed on the basis of a growing body of epidemiological data showing strong evidence for protection against CVD, type 2 diabetes and some cancers. The mechanistic evidence to support these claims is limited, and therefore there is a need for well-controlled intervention studies to underpin the health claims and provide evidence on which to develop public health strategies to promote whole-grain consumption. In the UK the Food Standards Agency has recently commissioned two such intervention studies based in the University of Newcastle (jointly with the MRCHNR, Cambridge, and involving Cereal Partners UK) and the University of Aberdeen (jointly with the Rowett 
Research Institute and Robert Gordon University) under the Diet and Cardiovascular Health Research Programme (N02). These projects are the first large-scale longer-term (16-week) interventions to be carried out using wholegrain foods that can readily be incorporated into the diet in order to meet the target levels suggested in the US Department of Agriculture (2005) dietary guidelines for Americans. For both studies outcome variables include comprehensive measures of CVD risk factors, e.g. blood lipid profiles, haemostatic and inflammatory markers, and anthropometric measures. These studies, which are expected to report by the end of 2007, will make an important contribution to the knowledge of the consequences of increased consumption of whole grains on cardiovascular risk.

\section{Acknowledgements}

The author is grateful for financial support from the Biotechnology and Biological Sciences Research Council, The Food Standards Agency, the University of Newcastle upon Tyne, Nestlé UK and Cereal Partners UK. The views expressed in this article are those of the author alone.

\section{References}

Adlercreutz H, Bannwart C, Wahala K, Makela T, Brunow G, Hase T, Arosemena PJ, Kellis JJT \& Vickery LE (1993) Inhibition of human aromatase by mammalian lignans and isoflavonoid phytoestrogens. Journal of Steroid Biochemistry and Molecular Biology 44, 147-153.

Adom KK \& Liu RH (2002) Antioxidant activity of grains. Journal of Agricultural and Food Chemistry 50, 6182-6187.

Ajani U, Ford E \& Mokdad A (2004) Dietary fiber and C-reactive protein: findings from National Health and Nutrition Examination Survey data. Journal of Nutrition 134, 1181-1185.

American Association of Cereal Chemists (2005) Definition/ Reports. http://www.aaccnet.org/definitions/wholegrain.asp (accessed August 2005)

American Heart Association (2005) American Heart Association publications and resources. http://www.americanheart.org/ presenter.jhtml ?identifier $=1200020($ accessed August 2005)

Anderson JW (2003) Whole grains protect against atherosclerotic cardiovascular disease. Proceedings of the Nutrition Society 62, 135-142

Anderson JW (2004) Whole grains and coronary heart disease: the whole kernel of truth. American Journal of Clinical Nutrition 80, 1459-1460.

Anderson JW, Hanna TJ, Peng X \& Kryscio RJ (2000) Whole grain foods and heart disease risk. Journal of the American College of Nutrition 19, 291S-299S.

Bach Knudsen K, Serena A, Kjaer A, Tetens I, Heinonen S-M, Nurmi T \& Adlercreutz H (2003) Rye bread in the diet of pigs enhances the formation of enterolactone and increases its levels in plasma, urine and feces. Journal of Nutrition 133, 1368-1375.

Benzie I \& Strain J (1996) The ferric reducing ability of plasma (FRAP) as a measure of 'antioxidant power': The FRAP assay. Analytical Biochemistry 239, 70-76.

Bowey E, Adlercreutz H \& Rowland I (2003) Metabolism of isoflavones and lignans by the gut microflora: a study in germfree and human micro flora associated rats. Food and Chemical Toxicology 41, 631-636.

British Heart Foundation (2005) British Heart Foundation statistics website. http://www.heartstats.org/datapage.asp?id=5340 (accessed August 2005)
Brown AA \& Hu FB (2001) Dietary modulation of endothelial function: implications for cardiovascular disease. American Journal of Clinical Nutrition 73, 673-686.

Byrnes S, Miller J \& Denyer G (1995) Amylopectin starch promotes the development of insulin-resistance in rats. Journal of Nutrition 125, 1430-1437.

Cao G \& Prior R (1998) Comparison of different analytical methods for assessing total antioxidant capacity of human serum. Clinical Chemistry 44, 1309-1315.

Daly M, Vale C, Walker M, Alberti K \& Mathers J (1997) Dietary carbohydrates and insulin sensitivity: a review of the evidence and clinical implications. American Journal of Clinical Nutrition 66, 1072-1085.

Ells LJ, Seal CJ, Kettlitz B, Bal W \& Mathers JC (2005) Postprandial glycaemic, lipaemic and haemostatic responses to ingestion of rapidly- and slowly-digested starches in healthy young women. British Journal of Nutrition 96, 948-955.

Erkkilä AT, Herrington DM, Mozaffarian D \& Lichtenstein AH (2005) Cereal fiber and whole-grain intake are associated with reduced progression of coronary-artery atherosclerosis in postmenopausal women with coronary artery disease. American Heart Journal 150, 94-101.

Esposito K, Pontillo A, Di Palo C, Giugliano G, Masella M, Marfella R \& Giugliano D (2003) Effect of weight loss and lifestyle changes on vascular inflammatory markers in obese women: A randomized trial. Journal of the American Medical Association 289, 1799-1804.

Festa A, D'Agostino R, Mykkanen L, Tracy R, Zaccaro D, Hales C \& Haffner S (1999) Relative contribution of insulin and its precursors to fibrinogen and PAI-1 in a large population with different states of glucose tolerance: the Insulin Resistance Atherosclerosis Study (IRAS). Arteriosclerosis, Thrombosis, and Vascular Biology 19, 562-568.

Food and Drug Administration (2003) Health claim notification for whole grain foods with moderate fat content. http:// www.cfsan.fda.gov/ dms/flgrain2.html (accessed August 2005)

Food and Drug Administration (1999) Health claim notification for whole grain foods. http://www.cfsan.fda.gov/ dms/ flgrains.html (accessed August 2005)

Foster-Powell K \& Brand-Miller J (1995) International tables of glycemic index. American Journal of Clinical Nutrition 65, 871S-893S.

Fraser GE (1999) Associations between diet and cancer, ischemic heart disease, and all-cause mortality in non-Hispanic white California Seventh-day Adventists. American Journal of Clinical Nutrition 70, 532S-538S.

Frost G, Leeds A, Trew G, Magara R \& Dornhorst A (1998) Insulin sensitivity in women at risk of coronary heart disease and the effect of a low GI food. Metabolism 47, $1245-1251$.

Fung TT, Hu FB, Pereira MA, Liu S, Stampfer MJ, Colditz GA \& Willet WC (2002) Whole-grain intake and the risk of type 2 diabetes: a prospective study in men. American Journal of Clinical Nutrition 76, 535-540.

Fung TT, McCullough ML, Newby P, Manson JE, Meigs JB, Rifai N, Willett WC \& Hu FB (2005) Diet-quality scores and plasma concentrations of markers of inflammation and endothelial dysfunction. American Journal of Clinical Nutrition 82, 163-173.

Golden S, Folsom A, Coresh J, Sharrett A, Szkio M \& Brancati F (2002) Risk factor groupings related to insulin resistance and their synergistic effects on subclinical atherosclerosis: the Atherosclerosis Risk in Communities Study. Diabetes 51, 3069-3076.

Grace PB, Taylor JI, Botting NP, Fryatt T, Oldfield MF, AlMaharik N \& Bingham SA (2003) Quantification of isoflavones and lignans in serum using isotope dilution liquid 
chromatography/tandem mass spectrometry. Rapid Communications in Mass Spectrometry 17, 1350-1357.

Haffner S (2003) Insulin resistance, inflammation, and the prediabetic state. American Journal of Cardiology 92, 18J-26J.

Hallfrisch J, Scholfield DJ \& Behall KM (2003) Blood pressure reduced by whole grain diet containing barley or whole wheat and brown rice in moderately hypercholesterolemic men. Nutrition Research 23, 1631-1642.

Halliwell B, Aeschbach R, Loliger J \& Aruoma OI (1995) The characterization of antioxidants. Food and Chemical Toxicology 33, 601-617.

Hallmans G, Zhang JX, Lundin E, Stattin P, Johansson A, Johansson I, Hulten K, Winkvist A, Lenner P, Aman P \& Adlercreutz H (2003) Rye, lignans and human health. Proceedings of the Nutrition Society 62, 193-199.

Halvorsen BL, Holte K, Myhrstad MCW, Barikmo I, Hvattum E, Remberg SF et al. (2002) A systematic screening of total antioxidants in dietary plants. Journal of Nutrition 132, 461-471.

Horner NK, Kristal AR, Prunty JA, Skor HE, Potter JD \& Lampe JW (2002) Dietary determinants of plasma enterolactone. Cancer Epidemiology, Biomarkers \& Prevention 11, 121-126.

Jacobs DR, Meyer KA, Kushi LH \& Folsom AR (1998) Wholegrain intake may reduce the risk of ischemic heart disease death in postmenopausal women: the Iowa Women's Health Study. American Journal of Clinical Nutrition 68, 248-257.

Jacobs DR, Meyer KA, Kushi LH \& Folsom AR (1999) Is whole grain intake associated with reduced total and cause-specific death rates in older women? The Iowa Women's Health Study. American Journal of Public Health 89, 322-329.

Jacobs DR, Meyer HE \& Solvoll K (2001) Reduced mortality among whole grain bread eaters in men and women in the Norwegian County Study. European Journal of Clinical Nutrition 55, 137-143.

Jacobs DR, Pereira MA, Meyer KA \& Kushi LH (2000) Fiber from whole grains, but not refined grains is inversely associated with all-cause mortality in older women: the Iowa Women's Health Study. Journal of the American College of Nutrition 19, 326S-330S.

Jensen MK, Koh-Banerjee P, Hu FB, Franz M, Sampson L, Gronbaek M \& Rimm EB (2004) Intakes of whole grains, bran, and germ and the risk of coronary heart disease in men. American Journal of Clinical Nutrition 80, 1492-1499.

Johnsen N, Hausner H, Olsen A, Tetens I, Christensen J, Knudsen K, Overvad K \& Tjonneland A (2004) Intake of whole grains and vegetables determines the plasma enterolactone concentration of Danish women. Journal of Nutrition 134, 2691-2697.

Jones AR, Hepples ML, Coulson J, Kuznesof S, Richardson DP \& Seal CJ (2004a) Increased wholegrain food consumption and indicators of adiposity: preliminary results from the CHEW-IT study. Proceedings of the Nutrition Society 63, 70A.

Jones AR, Kuznesof S, Richardson DP \& Seal CJ (2004b) Barriers to the consumption of wholegrain foods. Proceedings of the Nutrition Society 63, 96A.

Kähkonen MP, Hopia AI, Vuorela HJ, Rauha J-P, Pihlaja K, Kujala TS \& Heinonen M (1999) Antioxidant activity of plant extracts containing phenolic compounds. Journal of Agricultural and Food Chemistry 47, 3954-3962.

Katz R, Ratner R, Cohen R, Eisenhower E \& Verme D (1999) Are insulin and proinsulin independent risk markers for premature coronary artery disease? Diabetes $\mathbf{4 5}, 736-741$.

Kilkkinen A, Stumpf K, Pietinen P, Valsta L, Tapanainen H \& Adlercreutz H (2001) Determinants of serum enterolactone concentration. American Journal of Clinical Nutrition 73, 1094-1100.

Kilkkinen A, Valsta L, Virtamo J, Stumpf K, Adlercreutz H \& Pietinen P (2003) Intake of lignans is associated with serum enterolactone concentration in Finnish men and women. Journal of Nutrition 133, 1830-1833.

Koh-Banerjee P, Franz M, Sampson L, Liu S, Jacobs DR Jr, Spiegelman D, Willett W \& Rimm E (2004) Changes in whole-grain, bran, and cereal fiber consumption in relation to 8 -y weight gain among men. American Journal of Clinical Nutrition 80, 1237-1245.

Kreijkamp-Kaspers S, Kok L, Bots ML, Grobbee DE \& van der Schouw YT (2005) Dietary phytoestrogens and plasma lipids in Dutch postmenopausal women; a cross-sectional study. Atherosclerosis 178, 95-100.

Langley-Evans SC (2000) Consumption of black tea elicits an increase in plasma antioxidant potential in humans. International Journal of Food Sciences and Nutrition 51, 309-315.

Leenen R, Roodenburg AJC, Tijburg LBM \& Wiseman SA (2000) A single dose of tea with or without milk increases plasma antioxidant activity in humans. European Journal of Clinical Nutrition 54, 87-92.

Liese AD, Roach AK, Sparks KC, Marquart L, D'Agostino RB Jr \& Mayer-Davis EJ (2003) Whole-grain intake and insulin sensitivity: the Insulin Resistance Atherosclerosis Study. American Journal of Clinical Nutrition 78, 965-971.

Liu S, Manson J, Buring J, Stampfer M, Willett W \& Ridker P (2002) Relation between a diet with a high glycemic load and plasma concentrations of high-sensitivity C-reactive protein in middle-aged women. American Journal of Clinical Nutrition 75, 492-498.

Liu S, Manson JE, Stampfer MJ, Hu FB, Giovannucci E, Colditz GA, Hennekens $\mathrm{CH} \&$ Willett WC $(2000 a)$ A prospective study of whole-grain intake and risk of type 2 diabetes mellitus in US women. American Journal of Public Health 90, 1409-1415.

Liu S, Manson J, Stampfer MJ, Rexrode KM, Hu FB, Rimm EB \& Willett WC (2000b) Whole grain consumption and risk of ischemic stroke in women: A prospective study. Journal of the American Medical Association 284, 1534-1540.

Liu S, Stampfer MJ, Hu FB, Giovannucci E, Rimm E, Manson JE, Hennekens CH \& Willett WC (1999) Whole-grain consumption and risk of coronary heart disease: results from the Nurses' Health Study. American Journal of Clinical Nutrition 70, 412-419.

Liu S, Willett WC, Manson JE, Hu FB, Rosner B \& Colditz G (2003) Relation between changes in intakes of dietary fiber and grain products and changes in weight and development of obesity among middle-aged women. American Journal of Clinical Nutrition 78, 920-927.

Lopez-Garcia E, Schulze MB, Fung TT, Meigs JB, Rifai N, Manson JE \& Hu FB (2004) Major dietary patterns are related to plasma concentrations of markers of inflammation and endothelial dysfunction. American Journal of Clinical Nutrition 80, 1029-1035.

McKeown NM, Meigs JB, Liu S, Wilson PWF \& Jacques PF (2002) Whole-grain intake is favorably associated with metabolic risk factors for type 2 diabetes and cardiovascular disease in the Framingham Offspring Study. American Journal of Clinical Nutrition 76, 390-398.

Macko SA, Lubec G, Teschler-Nicola M, Andrusevich V \& Engel MH (1999) The Ice Man's diet as reflected by the stable nitrogen and carbon isotopic composition of his hair FASEB Journal 13, 559-562.

Milder IEJ, Feskens EJM, Arts ICW, de Mesquita HBB, Hollman PCH \& Kromhout D (2005) Intake of the plant lignans secoisolariciresinol, matairesinol, lariciresinol, and pinoresinol in Dutch men and women. Journal of Nutrition 135, 1202-1207.

Morris JN, Marr JW \& Clayton DG (1977) Diet and heart: a postscript. British Medical Journal 2, 1307-1314. 
Nagah AMS (2005) Antioxidant properties of wholegrain foods and the effect of wholegrain consumption on antioxidant status and lignan metabolism. PhD Thesis, University of Newcastle upon Tyne.

Nagah AMS, Nurmi T \& Seal CJ (2004) Consumption of wholegrain wheat, rye and rice by laboratory animals is associated with elevated plasma concentrations, urinary excretion and faecal output of enterolactone. Proceedings of the Nutrition Society 63, 93A.

Nagah AMS \& Seal CJ (2005) In vitro procedure to predict apparent antioxidant release from wholegrain foods measured using three different methods. Journal of the Science of Food and Agriculture 85, 1177-1185.

Niemeyer HB, Honig DM, Kulling SE \& Metzler M (2003) Studies on the metabolism of the plant lignans secoisolariciresinol and matairesinol. Journal of Agricultural and Food Chemistry 51, 6317-6325.

Nurmi T \& Adlercreutz H (1999) Sensitive high-performance liquid chromatographic method for profiling phytoestrogens using coulometric electrode array detection: application to plasma analysis. Analytical Biochemistry 274, 110-117.

Pereira M, Jacobs D, Slattery M, Ruth K, Van Horn L, Hilner J \& Kushi L (1998) The association between whole grain intake and fasting insulin in a biracial cohort of young adults. The CARDIA study. CVD Prevention 1, 231-242.

Pereira MA (2002) Whole grain consumption and body weight regulation. In Whole Grain Foods in Health and Disease, pp. 233-242 [L Marquart, JL Slavin and RG Fulcher, editors]. St Paul, MN: American Association of Cereal Chemists.

Pereira MA, Jacobs DR, Pins JJ, Raatz SK, Gross MD, Slavin JL \& Seaquist ER (2002) Effect of whole grains on insulin sensitivity in overweight hyperinsulinemic adults. American Journal of Clinical Nutrition 75, 848-855.

Pereira MA, Pinns JJ, Jacobs DR, Marquart L \& Keenan J (2001) Whole grains, cereal fiber and chronic diseases: Epidemiological evidence. In CRC Handbook of Dietary Fiber in Human Nutrition, pp. 461-479 [GA Spiller, editor]. Boca Raton, FL: CRC Press.

Pietinen P \& Kilkkinen A (2002) Enterolactone and risk of cancer. Journal of Nutrition 132, 3535S-3536S

Pietinen P, Stumpf K, Mannisto S, Kataja V, Uusitupa M \& Adlercreutz H (2001) Serum enterolactone and risk of breast cancer: A case-control study in eastern Finland. Cancer Epidemiology, Biomarkers \& Prevention 10, 339-344.

Plutzky J (2003) The vascular biology of atherosclerosis. American Journal of Medicine 115, 55S-61S.

Qu H, Madl RL, Takemoto DJ, Baybutt RC \& Wang W (2005) Lignans are involved in the antitumor activity of wheat bran in colon cancer SW480 cells. Journal of Nutrition 135, 598-602.

Re R, Pellegrini N, Proteggente A, Pannala A, Yang M \& RiceEvans C (1999) Antioxidant activity applying an improved ABTS radical cation decolorization assay. Free Radical Biology and Medicine 26, 1231-1237.

Richardson DP (2003) Wholegrain health claims in Europe. Proceedings of the Nutrition Society 62, 1-9.

Ridker P (2001) High-sensitivity C-reactive protein: potential adjunct for global risk assessment in the primary prevention of cardiovascular disease in women. New England Journal of Medicine 103, 1813-1818.

Ross R (1999) Atherosclerosis: an inflammatory disease. New England Journal of Medicine 340, 115-126.

Saarinen NM, Warri A, Makela SI, Eckerman C, Reunanen M, Ahotupa M, Salmi SM, Franke AA, Kangas L \& Santti R (2000) Hydroxymatairesinol, a novel enterolactone precursor with antitumor properties from coniferous tree (Picea abies). Nutrition and Cancer 36, 207-216.
Seal CJ, Daly ME, Thomas LC, Bal W, Birkett AM, Jeffcoat R \& Mathers JC (2003) Postprandial carbohydrate metabolism in healthy subjects and those with type 2 diabetes fed starches with slow and rapid hydrolysis rates determined in vitro. British Journal of Nutrition 90, 853-864.

Shinozaki K, Suzuki M, Ikebuchi M, Hara Y \& Harano Y (1996) Demonstration of insulin resistance in coronary artery disease documented with angiography. Diabetes Care 19, 1-7.

Sies H, Stahl W \& Sevanian A (2005) Nutritional, dietary and postprandial oxidative stress. Journal of Nutrition 135, 969-972.

Slavin JL (2003) Whole grains are protective: biological mechanisms. Proceedings of the Nutrition Society 62, 129-134.

Smith AT, Kuznesof S, Richardson DP \& Seal CJ (2003) Behavioural, attitudinal and dietary responses to the consumption of wholegrain foods. Proceedings of the Nutrition Society 62, 455-467.

Southgate DAT (2000) Cereals and cereal products. In Human Nutrition and Dietetics, pp. 333-347 [JS Garrow, WPT James and A Ralph, editors]. London: Churchill Livingstone.

Steffen LM, Jacobs DR Jr, Stevens J, Shahar E, Carithers T \& Folsom AR (2003) Associations of whole-grain, refined-grain, and fruit and vegetable consumption with risks of all-cause mortality and incident coronary artery disease and ischemic stroke: the Atherosclerosis Risk in Communities (ARIC) Study. American Journal of Clinical Nutrition 78, 383-390.

Swedish Nutrition Foundation (2003) New generic health claim. http://www.snf.ideon.se/snf/en/rh/Wholegrain.htm (accessed August 2005)

Trowell H (1972) Ischemic heart disease and dietary fiber. American Journal of Clinical Nutrition 25, 926-932.

Trowell H (1979) Recent developments in dietary-fibre hypothesis. In Dietary Fibre: Current Developments of Importance to Health, pp. 1-8 [K Heaton, editor]. Westport, CT: Food and Nutrition Press.

US Department of Agriculture (2005) My pyramid. http:// www.mypyramid.gov/ (accessed August 2005)

Uwaifo GI \& Ratner RE (2003) The roles of insulin resistance, hyperinsulinaemia, and thiazolidinediones in cardiovascular disease. American Journal of Medicine 115, 12S-19S.

van der Schouw YT, Sampson L, Willett WC \& Rimm EB (2005) The usual intake of lignans but not that of isoflavones may be related to cardiovascular risk factors in U.S. men. Journal of Nutrition 135, 260-266.

Vanharanta M, Voutilainen S, Lakka T, van der Lee M, Adlercreutz H \& Salonen J (1999) Risk of acute coronary events according to serum concentrations of enterolactone: a prospective population-based case-control study. Lancet 354, 2112-2115.

Wiemer K (2002) Whole-grains health claims: supporting scientific evidence and the FDA Modernisation Act process. In Whole-Grain Foods in Health and Disease, pp. 327-340 [L Marquart, J Slavin and R Fulcher, editors]. St Paul, MN: American Association of Cereal Chemists.

Yudkin J, Stehouwer C, Emeis J \& Coppack S (1999) C-reactive protein in healthy subjects: Associations with obesity, insulin resistance, and endothelial dysfunction - A potential role for cytokines originating from adipose tissue? Arteriosclerosis, Thrombosis, and Vascular Biology 19, 972-978.

Zern TL \& Fernandez ML (2005) Cardioprotective effects of dietary polyphenols. Journal of Nutrition 135, 2291-2294.

Zielinski H \& Kozlowska H (2000) Antioxidant activity and total phenolics in selected cereal grains and their different morphological fractions. Journal of Agricultural and Food Chemistry 48, 2008-2016. 